\title{
INFLUENCE OF FORAGE HARVESTER CHOPPING EQUIPMENT ON CHARACTERISTICS OF CHIPS
}

\author{
Ancuta Nedelcu, Radu Ciuperca, Ana Zaica, Vasilica Stefan
}

National Institute of Research-Development for Machines and Installations

Designed to Agriculture and Food Industry, Romania

nedelcuus@yahoo.com, ciupercaradu@yahoo.com,zaica_ana@yahoo.com, valle_vali@yahoo.com

\begin{abstract}
The modern technologies for harvesting fodder for preservation are applied by using technical equipment that performs multiple operations (cutting, chopping, transporting) in a single pass, thus contributing to cost reduction and decrease of the losses during harvesting. Fodder harvesting for silage is mainly done with fodder harvesters, provided with harvesting equipment according to the operations in the technological process and fodder crop. This paper presents the experimental results obtained with a trailed fodder harvester on the main characteristics of the chopped material which can influence the quality of the silo: the chopping length of fodder plants and the uniformity of the chopping length. The process of compaction and air removal from the mass of chopped fodder are influenced by the chopping length of fodder plants and the uniformity of the chopping length, parameters realized by the chopping device of the harvesting equipment. In this paper a comparative analysis of the main types of chopping devices generally used on fodder harvesters was made and also the identification of their advantages and disadvantages, the quality of chopped material experimentally obtained for two types of harvested fodder (lucerne and vetch) and the energy consumption registered. The experiments were carried out in experimental fields at INMA Bucharest, with a trailed fodder harvester, in aggregate with an agricultural tractor of $58 \mathrm{~kW}$. The functional characteristics determined experimentally are summarized in tabular and graphical form and are useful to identify the best option for the chopping device and setting the operating mode depending on the characteristics of the culture to be harvested.
\end{abstract}

Keywords: fodder, harvesting, chopping drum, chopping lengths.

\section{Introduction}

The harvesting of fodder plants is a very important process in the preparation of animal feed, given that most of the plant production in Romania (over $80 \%$ ) is used in animal feed either directly or as by-products after prior processing to obtain food or raw materials [1].

The main fodder plants in arable land that are grown on large areas are lucerne, clover, corn silage, annual plants for hay and green mass. One of the most cultivated fodder plants is lucerne, a perennial plant mixed with grass [2], but the vetch crop can be an alternative, especially for farmers, who want to use the land also for setting up other crops. The vetch is a mixture of autumn vetch cultivated next to a cereal, such as rye or barley [3]. Depending on the time chosen for sowing, there is autumn or spring vetch.

The agricultural machinery industry is one of the fastest growing industries in the world. The most suitable machines for harvesting fodder plants for silage preservation are fodder harvesters that can carry out at the same time fodder harvesting and chopping with direct loading in transport trailers [4].

In general, a fodder harvester consists of two main parts: the basic machine and the working equipment. The basic machine of fodder harvesters contains the main subassemblies that carry out the process of chopping and discharging the material, namely (the feed system, the chopping device, the grain splitting device, the device for discharging the chopped fodder). The working equipment is classified according to the operations of the technological process and the fodder crop to be harvested, and known as: equipment for harvesting grassy fodder in the field; equipment for gathering fodder from the furrow; equipment for harvesting corn silage.

Forage harvesters are also classified according to the following criteria [1]: the feed flow; aggregation mode; type of harvesting equipment (header type) and the type of the chopping device.

In the technological process of fodder harvesting, the chopping device is of special importance; it performs the chopping of plants, by cutting them in fragments of dimensions between 8 and $100 \mathrm{~mm}$ and throwing them in the harvester discharge system, due to the peripheral speed and air flow created by it. The chopping device has the highest energy consumption, among the fodder harvester working parts [5]. 
The type of the chopping devices and the working regime determine the chopping length of the fodder plants and the uniformity of the chopping length, characteristics that influence the ensilage process [6].

The chopping devices used in fodder harvesters are divided into two groups:

1. Chopping devices with knives rigidly mounted on the actuator;

2. Chopping devices with hinged knives.

Harvesters with chopping devices with hinged knives, from a construction perspective, are simple, robust, light, inexpensive and easy to maintain machines, but are sensible to uneven terrain, which can drag soil into the harvested forage. The chopping length is not uniform and depends on the condition of the crops and the speed of movement, and the material losses are high compared to other types of harvesters.

Those with rigid mounted knives are more widespread, because they are safe during operation, ensure high uniformity of chopping length and allow for precise adjustment.

\section{Materials and methods}

The paper presents experimental results obtained using cutting devices with rigid mounted knives on the actuator.

These chopping devices are divided into two groups:

- chopping devices with drum mounted knives;

- chopping devices with disc mounted knives.

The knives can be straight (placed after the generatrices or inclined) or helical.

In case the drum also throws the chopped material, the knives are made in the form of helical blades, Fig. 1, or are mounted on the supports of the throwing blades.
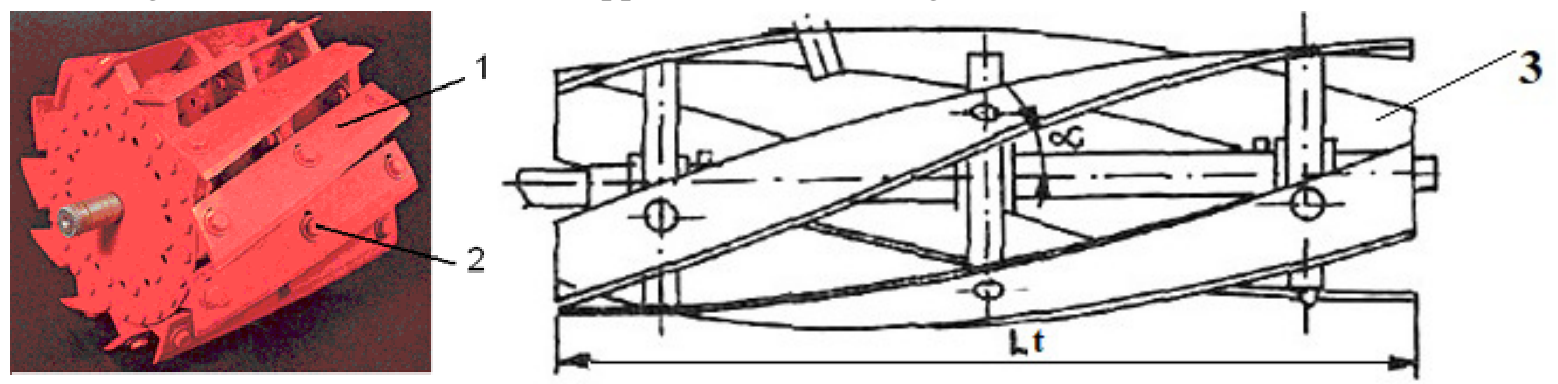

Fig. 1. Chopping drum with helical knives (New Holland 770): 1 - helical knife; 2 - fastening screws; 3 - scheme of the chopping device with helical knives; $\alpha$ - slip angle $\left(\alpha=12-30^{\circ}\right)$;

$L_{t}$ - length of the chopping drum, $\mathrm{mm}$.

The knives are arranged inclined to the drum generatrix at an angle of $6-12^{\circ}$ for the progressive cutting, and the knife edge is sharpened at an angle of $16-37^{\circ}$, the distance between the knife and the counterknife is $0.3-2.5 \mathrm{~mm}$. The peripheral speed at the drums that perform the chopping and throwing of the chopped material is up to $38.4 \mathrm{~m} \cdot \mathrm{s}^{-1}[1 ; 7]$.

The safety of the chopping drums is jeopardized by the stones and metal parts, which, incidentally, could be introduced together with the material in the working area of the knives. For the protection of the chopping parts, in addition to the metal detectors, multi-segment drums were made by dividing the working width of the knife into several small knives, Fig. 2.

The knives of the multi-knife chopping drum have elongated holes for adjusting and changing the knives, which are mounted with the help of pressing plates and screws, on some supports that ensure the evacuation of the chopped material.

The chopping length of the material is calculated by the formula (1), [7]:

$$
l_{t}=\frac{2 \pi \cdot v_{v}\left(1-\varepsilon_{a}\right)}{z \cdot \omega}
$$

where $l_{t}-$ chopping length, $\mathrm{mm}$; 
$v_{v}$ - peripheral speed of feed rollers, $\mathrm{m} \cdot \mathrm{s}^{-1}$;

$\varepsilon_{a}-$ slip coefficient of the rollers on the plant layer $\left(\varepsilon_{a}=0.07-0.4\right)$;

$z$ - number of knives on the drum;

$\omega-$ angular velocity of the chopping drum, $\mathrm{s}^{-1}$.

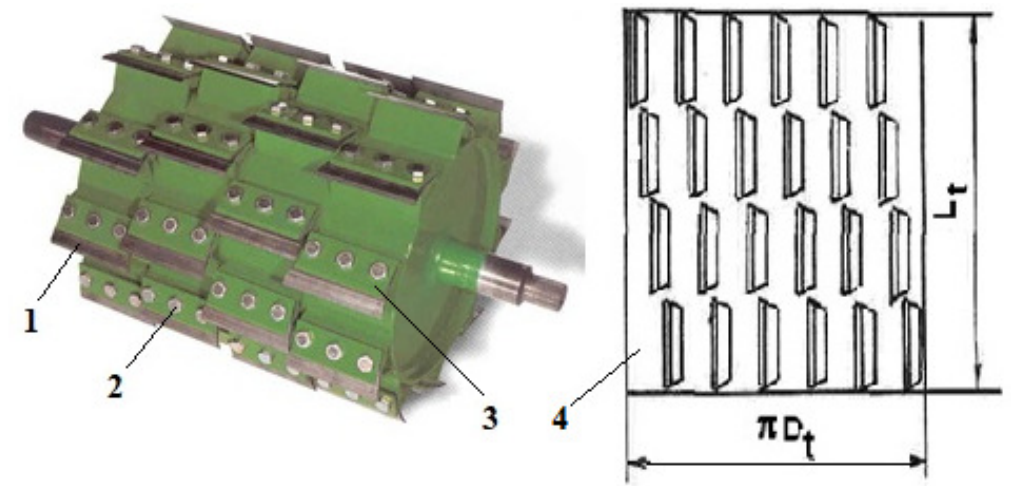

Fig. 2. Multi-knife chopping drum (John Deere 3760): 1 - cascading multi-segment knives;

2 - fastening screws; 3 - pressing plate; 4 - evolute of a multi-segment knife drum; $D_{t}$ - drum diameter, $\mathrm{mm}$

The position of the knife relative to the counterknife is determined provided that the material is not pushed sideways during cutting and the angle between the knife and counterknife on the drum generatrix should not exceed $10^{\circ}$. This displacement is amplified, if the knives are not well sharpened and the material is pushed toward the walls of the drum, with negative effects on energy consumption, increasing the danger of clogging. In order to eliminate these disadvantages, chopping drums were made with two rows of knives placed in "V", so that the eventual movement of the material between the knives and the counterknives may take place toward the centre of the drum, Fig.3.

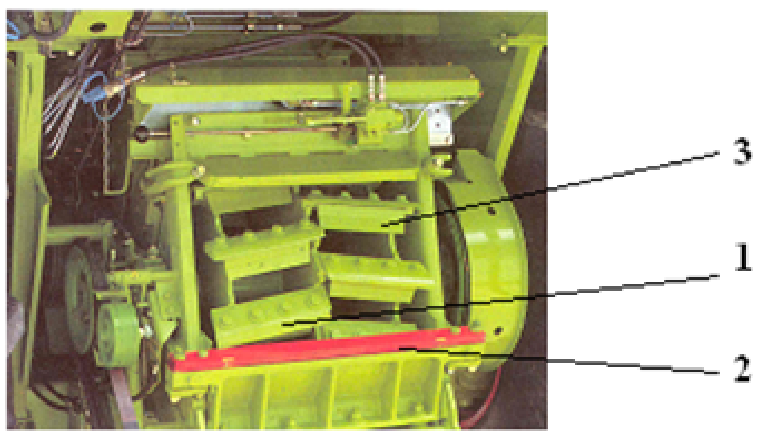

Fig. 3. Drum with two rows of knives placed in "V" (CLAAS):

1 - knife; 2 - counterknife; 3 - blade

As part of the research activities a trailed fodder harvester was made at INMA Bucharest, denoted $\mathrm{CTF}$, adapted to the work with three different pieces of equipment: equipment for harvesting corn silage crops; equipment for harvesting grassy fodder plants; equipment for plant gathering from the furrow.

The CTF harvester was tested under laboratory conditions with three variants of chopping devices: chopping drum with cascading knives and blades placed behind the knife support and inclined at $45^{\circ}$; chopping drum with knives placed in "V" without blades; chopping drum with knives placed in "V" with blades in front of the knife support and perpendicular to it.

According to the authors [5], during the experiments under laboratory conditions, the cascading knife chopping drum achieved higher indices (lower driving power, higher airflow velocity) than those with "V" placed knives with or without blades.

The tests continued under laboratory-field conditions for harvesting corn silage (results were presented in [5]). 
In this article the authors present the results obtained during the harvesting of lucerne and vetch by the CTF harvester equipped with a cascading knife chopping device, Fig.4, and in conjunction with the equipment for harvesting grassy fodder plants.

The tests were carried out on lands cultivated with lucerne and vetch at SC AGROINDUSTRIALA Pantelimon S.A.
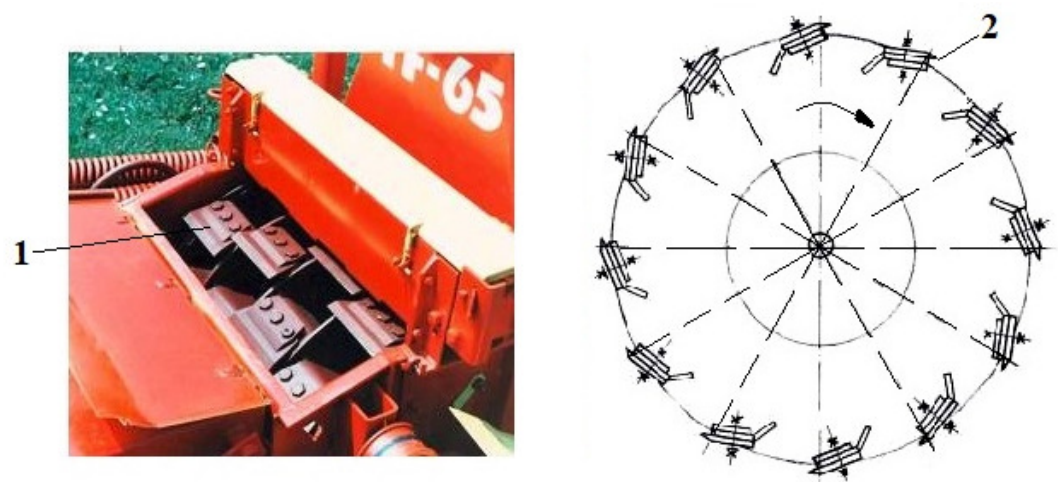

Fig. 4. Cascading knife chopping drum: 1 - cascading knife drum and blades mounted on the CTF; 2 - scheme of cascading knife chopping drum

The working conditions and the composition of the harvested plants are presented in Table 1.

Table 1

\section{Land and harvested plant characteristics}

\begin{tabular}{|c|c|c|c|}
\hline \multirow{2}{*}{\multicolumn{2}{|c|}{ Index name }} & \multicolumn{2}{|c|}{ Crop } \\
\hline & & Lucerne I mowing & Vetch \\
\hline \multicolumn{2}{|c|}{ Green mass production per hectare, $\mathrm{T}$} & 12.7 & 15.4 \\
\hline \multicolumn{2}{|c|}{ Average height of the field, $\mathrm{mm}$} & 510 & 610 \\
\hline \multicolumn{2}{|c|}{ Average length of plants, $\mathrm{mm}$} & 550 & 670 (oat) \\
\hline \multicolumn{2}{|c|}{ Humidity, $\%$} & 74.8 & 71.2 \\
\hline \multicolumn{2}{|l|}{ Vegetation stage } & $50 \%$ in bloom & $\begin{array}{l}100 \% \text { with ears and pods } \\
\text { formed }\end{array}$ \\
\hline \multirow{4}{*}{$\begin{array}{l}\text { Botanical } \\
\text { composition, \% }\end{array}$} & lucerne & 93 & \\
\hline & oat & & 57 \\
\hline & pea & & 40 \\
\hline & other plants (weeds) & 7 & 3 \\
\hline \multicolumn{2}{|l|}{ Landform } & lowland & lowland \\
\hline \multicolumn{2}{|l|}{ Soil condition } & slightly loose & slightly loose \\
\hline
\end{tabular}

\section{Results and discussion}

The operating indices of the trailed fodder harvester CTF were determined in the period June to July 2018. A volume of $154 \mathrm{t}$ was obtained at lucerne harvesting and $215 \mathrm{t}$ at vetch harvesting.

The laboratory indices presented in Table 2 were determined under the following conditions:

- tractor used: U650;

- rated engine speed, $1800 \mathrm{rpm}$;

- power take-off speed, $540 \mathrm{rpm}$;

- theoretical chopping length, $20 \mathrm{~mm}$ and $26 \mathrm{~mm}$.

The average values of the working indices obtained during the tests are presented in Table 2. The tests showed that the optimum working speed is between $0.73-1.75 \mathrm{~m} \cdot \mathrm{s}^{-1}$, depending on the production of green mass per ha.

In working conditions with speeds up to $1.75 \mathrm{~m} \cdot \mathrm{s}^{-1}$ and wind speeds up to $1.5 \mathrm{~m} \cdot \mathrm{s}^{-1}$, the total material losses are not high, reaching up to $2.6 \%$. 
Trials were carried out in accordance with the specific testing procedure for feed harvesters developed by the institution SppI-01.00.04.

Average values of qualitative working indices

\begin{tabular}{|l|c|c|}
\hline \multirow{2}{*}{ Index name } & \multicolumn{2}{c|}{ Determined value } \\
\cline { 2 - 3 } & Lucerne I mowing & Vetch \\
\hline Actual working width, mm & 2000 & 2000 \\
\hline Cutting height, mm & $63-65$ & $85-90$ \\
\hline Working speed, m s & 1.75 & 1.75 \\
\hline Material throwing distance (average value), $\mathrm{m}$ & 5.6 & 5.2 \\
\hline \multicolumn{2}{|c|}{ Material losses, \% } \\
\hline Uncut plants remained in the field & $<1$ & $<1$ \\
\hline Chopped plant mass fallen on the ground & 1.3 & 1.6 \\
\hline
\end{tabular}

The feed chopping length is adjusted by changing the speed of the machine feed rollers by acting on the gear transmission in the machine distribution box.

To determine the degree of chopping for different values of the theoretical chopping length, a quantity of material $(0.100-0.200 \mathrm{~kg})$ is extracted from the mass of chopped material, the mass is separated and grouped on chopping length intervals, the degree of chopping is weighed and calculated in $\%$.

Table 3 presents the average values obtained on these measurements for the theoretical chopping length of $20 \mathrm{~mm}$ and $26.8 \mathrm{~mm}$, respectively, for lucerne / vetch crops.

Table 3

Average chopping degree resulted in lucerne and vetch harvesting

\begin{tabular}{|c|c|c|c|c|}
\hline \multirow{2}{*}{$\begin{array}{c}\text { Length range, } \\
\mathbf{m m}\end{array}$} & \multicolumn{3}{|c|}{ Theoretical chopping length adjusted to the chopping device } \\
\cline { 2 - 5 } & \multicolumn{2}{|l}{$\boldsymbol{l}_{\boldsymbol{t}} \mathbf{2 0 . 0} \mathbf{~ m m}$} & \multicolumn{2}{c|}{$\boldsymbol{l}_{\boldsymbol{t}} \mathbf{= 2 6 . 8} \mathbf{~ m m}$} \\
\hline & Mass, $\mathbf{g}$ & $\mathbf{\%}$ & Mass, $\mathbf{g}$ & $\mathbf{\%}$ \\
\hline \multirow{2}{*}{$0-10$} & 45.50 & 26.76 & $\begin{array}{c}23.50 \\
\text { (of which } 21.6 \text { are small } \\
\text { leaves) }\end{array}$ & $\begin{array}{c}24.37 \\
\text { (of which 22.4 are } \\
\text { small leaves) }\end{array}$ \\
\hline $10.1-20$ & 35.30 & 20.76 & 26.20 & 28.20 \\
\hline $20.1-30$ & 35.80 & 21.10 & 18.80 & 19.30 \\
\hline $30.1-40$ & 29.80 & 17.53 & 7.50 & 7.85 \\
\hline $40.5-50$ & 12.3 & 7.23 & 7.10 & 7.50 \\
\hline $50.1-60$ & 2.20 & 1.29 & 5.30 & 5.50 \\
\hline $60.1-70$ & 1.90 & 1.10 & 2.20 & 2.28 \\
\hline $70.1-80$ & 1.30 & 0.76 & 1.30 & 1.30 \\
\hline $80.1-100$ & 3.40 & 2.00 & 3.20 & 2.40 \\
\hline$>100$ & 2.50 & 1.47 & 1.20 & 1.30 \\
\hline TOTAL & 170 & 100 & 96.30 & 100 \\
\hline
\end{tabular}

Doing a comparative analysis of the dimensions of chopped lucerne and vetch materials with the dimensions of the corn silage presented in paper [5], it is found that for a theoretical adjustment on the drum of $26.8 \mathrm{~mm}$, the particles with the length up to $30 \mathrm{~mm}$ represent $60.42 \%$ for lucerne / vetch, with $1.02 \%$ more than in corn silage where $59.4 \%$ was obtained. Also, the percentage of losses for particles exceeding a lenth of $100 \mathrm{~mm}$ is in the same range, arround $1.3 \%$

The objective of agricultural machine manufacturers is to develop chopping drums that ensure a wide range of cutting lengths from 3 to $33 \mathrm{~mm}$, depending on the model and configuration of the chopping knives.

According to [8], the use of a shredded fodder with short dimensions for dairy cow feed increases the yield of milk, protein and lactose. 


\section{Conclusions}

The Following those presented, the following main conclusions can be drawn.

1. When harvesting lucerne and vetch with the machine equipped with a cascading knife chopping system, it is found that particles with a length of up to $30 \mathrm{~mm}$ represent $68.62 \%$ for a theoretical adjustment of chopping lengths of $20 \mathrm{~mm}$, and $60.42 \%$ for a theoretical adjustment of $26.8 \mathrm{~mm}$.

2. It is also found that about $90 \%$ of chopped particles have a length of up to $50 \mathrm{~mm}$, and only a small percentage of 1.3-2.5\% exceed the length of $100 \mathrm{~mm}$.

3. Using the cascading knife chopper machine produced a mince with dimensions of 3-33 mm (recommended for silage) in a percentage of over $60 \%$ when harvesting vetch and lucerne.

4. Because the size of the mince influences the quality of the preserved feed, the obtained results indicate the importance of having systems for adjusting the chopping length as part of the workflow.

\section{Acknowledgements}

The research work was funded by a financing grant of the Romanian Research and Innovation Ministry, through Programme 1 - subprogramme 1.2 - Institutional performance - Projects for financing excellence in RDI, contract No. 16PFE.

\section{References}

[1] Voicu E., Tehnologii şi echipamente tehnice pentru recoltarea şi însilozarea plantelor furajere (Technologies and technical equipment for harvesting and ensilage of fodder plants), "TERRA NOASTRA" Publishing House Iasi, Romania, 2010.

[2] Hakl J., Pisarčik M., Fuksa P., etc., Development of lucerne root morphology traits in lucernegrass mixture in relation to forage yield and root disease score. Field Crops Research, vol.226, 2018, pp. 66-73.

[3] Lithourgidisa A.S., Vasilakogloub I.B., Dhimac K.V., etc. Forage yield and quality of common vetch mixtures with oat and triticale in two seeding ratios. Field Crops Research, vol. 99, Issues 2 3, 2006, pp. 106-113.

[4] Nedelcu A., Popa D.L., Ciuperca R., etc. Experimental research with forage harvester for ensilage. International Symposium ISB-INMA TEH 2019 "Agricultural and Mechanical Engineering", 2019, Bucharest, Romania, pp. 355-360.

[5] Păun A., Nedelcu A., Neagoe V., (2012), Researches Regarding the Optimization of Fodder Combines Chopping Drums. INMATEH Agricultural Engineering, vol. 38, no. 3, 2012, pp. 33-38.

[6] Pitt R.E., Gebremedhin K.G., Effects of forage species, chopping length, moisture content, and harvest number on tower silo capacity and wall loads, Journal of Agricultural Engineering Research, Vol.44, 1989, pp. 205-215.

[7] Niculăiasa V., Dănilă I., Procese de lucru şi maşini agricole de recoltare (Work processes and agricultural harvesting machines), Publishing house A 92, Iaşi, Romania, 1995, pp. 195-216.

[8] Kmicikewycz A.D., A. J.Heinrichs, Effect of corn silage particle size and supplemental hay on rumen $\mathrm{pH}$ and feed preference by dairy cows fed high-starch diets, Journal of Dairy Science, Vol.98, Issue 1, 2015, pp. 375-385. 